Agro-Science Journal of Tropical Agriculture, Food, Environment and Extension Volume 16 Number 3 (September 2017) pp. $37-45$

ISSN 1119-7455

\title{
ASSESSMENT OF THE PHYSICAL AND MECHANICAL PROPERTIES OF THE SOILS IN THE DIFFERENT AGROECOLOGICAL ZONES OF BENIN
}

\author{
Dayou, E.D. ${ }^{{ }^{*}}$ Zokpodo, K.L.B. $^{1}$ Glèlè Kakaï L.R. $^{2}$ \\ ${ }^{1}$ School of Environmental Management, Faculty of Agronomic Sciences, University of \\ Abomey-Calavi 01 BP 526 Cotonou, Benin \\ ${ }^{2}$ Laboratory of Biomathematics and Forestry Estimations, Faculty of Agronomic Sciences, \\ University of Abomey-Calavi 04 BP 1525 Cotonou, Benin \\ Author for correspondences: phreddoss1@yahoo.fr
}

\begin{abstract}
The physical properties of soils are important for proper monitoring of soil functions. In order to evaluate soil resistance to agricultural equipment, a study was carried out on the four main soil types (ferralitic, ferruginous, hydromorphic and vertisol) in the eight agroecological zones of Benin. The objective of this work was to determine the physical and mechanical parameters of the soils. A sampling of soil types by agroecological zone was carried out in 36 localities in Benin to record vertical and horizontal soil strengths using a compactometer and a penetrometer. These data were complemented by measurements of texture, density and water content of the soil samples. An analysis of variance, polynomial regressions and Pearson correlation were performed between the parameters studied. It is noted that majority of soils assessed were sandy loam. The high sand content in most soils would be due to the depth considered $(20 \mathrm{~cm})$. The bulk densities range from 1.21 to $1.73 \mathrm{gcm}^{-3}$ and water contents from 4.9 to $35.11 \%$. Vertical resistances range from 3.89 to $16.36 \mathrm{~kg} \mathrm{~cm}^{-2}$ and horizontal resistances from 1.03 to $4.44 \mathrm{~kg} \mathrm{~cm}^{-2}$. Strong soil resistances (vertical and horizontal) are recorded in the northern part of Benin where large proportions of the gravelswere observed in the samples taken. A positive correlation was observed between vertical resistance and horizontal soil resistance. It can be concluded that soil resistance in Benin vary from one agro-ecological zone to another, but the linking of soil properties is less significant between zones.
\end{abstract}

Keywords: Soil compaction, soil resistance, penetrometer, agroecological zones, Benin

\section{INTRODUCTION}

Soil occupies a special position because of its agronomic and environmental functions in the preservation of natural resources. However, land degradation is becoming a growing problem worldwide (Ball et al. 2015). Various processes, in particular the collapse followed by erosion, contribute to this soil degradation (Abdellaoui et al. 2011). Many studies have evaluated the negative consequences of land degradationon agricultural production (Adnan et al. 2017, Mekhlouf et al. 2011). Soil compaction, characterized by reduction of macrospores, available water and thus productivity (Birkas et al. 2008) can be evaluated by measuring soil density and penetrometer resistance. When these properties exceed critical values, plant growth is severely restricted (Medeiros et al. 2010). Several factors influence soil compaction which may include different tillage tools, depth and speed of ploughing, moisture content, texture or soil cover residue (Bogunovic et al. 2016). Experimental results studied variations of crop yield as a function of the level of subsidence of the surface horizons (Richard, 2008) but the influence of soil stress on the strength of agricultural equipment has been less studied. To study these constraints, two approaches could be adopted: laboratory methods or in situ methods. Laboratory testing allows for high control of limit conditions, deformation rates, and drainage conditions on soil samples. However, they are expensive, require long preparation and completion times, and only provide discrete values at selected locations (Ali, 2010). In comparison, field tests are fast while testing the soil in its natural environment, and provide immediate results, according to Ali (2010). It is true that all intrinsic properties and mechanical parameters of soils are never known with a high degree of precision or reliability, because of the natural variability of the materials constituting the soil. 
However, the use of a simpler and portable penetrometer is one of the means for rapid collection of soil characteristics (Dexter et al. 2007, Lenoble and Martinaud, 2003). Indeed, resistance to soil penetration is one of the most common indicators of soil physical properties in agronomic assessment (Daniel et al. 2015, Ajayi et al. 2009). Several studies have shown the penetrometer's ability to distinguish spatial variations in mechanical properties in natural soils (Steve and Caroline, 2017 ; Lepetit et al. 2000). The results of a soil penetration test can be used to evaluate soil type, soil density and in situ stress status (Ali, 2010). Just as soil resistance to the penetrometer can be predicted from moisture content and soil density (Whalley et al., 2007), it would be interesting to make an inverse prediction. For the geotechnician, the homogeneous layer of the soil is presented as three-dimensional zone where vertical layer is often preferred, the results supposed to be extended for the horizontal layers (Breysse et al., 2002). To be reassured, it appears necessary to evaluate the soil resistance, not only according to the depth, but also on the horizontal and to establish a relationship between them. It is expensive and tedious to measure all the parameters on a large number of points on the same site. It is in this context that the establishment of relationships between the soil parameters measured in the laboratory (density, water content, grain size) and those easily measurable and at a lower cost in situ such as penetrometer resistance can contribute effectively to the extension of the results. The objective of this research is to assess the vertical and horizontal resistance of soils, to establish a relationship between these two parameters and their relationship to the water content, the soil density and the soil particle size. This makes it possible to highlight and predict the resistance of the different soils to agricultural equipment.

\section{MATERIAL AND METHODS \\ Area of study}

This study was carried out in eight agroecological zones of Benin (Figure 1).This division was based on the definition of relatively homogeneous zones using agropedological parameters (climate, soil and vegetation), cropping systems and demography (UNDP / ECVR, 1995; Gbemavo et al., 2014). Table 1: Pedoclimatic characteristics and main crops cultivated in each agroecological zone of Benin Source : Willaime and Volkoff (1967); UNDP/ECVR (1995); MAEP (2010); Gbemavo et al. (2014).

\section{Sampling}

In each agroecological zone, oneto two municipalities were randomly selected, based on each major type of soil in Benin (ferralitic, ferruginous, hydromorphic and vertisol). A total of 12 municipalities were visited as part of this study and, by municipality of study, three villages were selected for data collection. Thus, 36 villages of were covered for data collection.The criteria for selecting villages are: important cereal crops (maize) and legumes (cowpea, soybean, peanut) that were used in the design of the seeder. These are the villages of Bodjecali, Guéné I, Garou I (Municipality of Malanville); Wagou, Gomparou A, Simparou (Municipality of Banikoara); Pedarou, Gamia Est, Gando (Municipality of Bembèrèkè); Serou, Barienou, Donga (Municipality of Djougou); Koutagou, Koutayagou, Koukoua (Municipality of Boukoumbé); Erokowari, Igoho, Moumoudji (Municipality of Dassa); Sekou-Denou, Attogon, Ahota (Municipality of Allada); Adjaha, Todjonkoun, Seho-Condji (Municipality of Grand-Popo); HouingaSalahoué, Doutou, Manonkpon (Municipality of Houéyogbé); Gouloko, Gnizounme, Ahomadegbe (Municipality of Lalo); Sissekpa, Gbekandji, Gbada (Municipality of Adjohoun); Itchedè, Oko Akaré, Ikplinlè (Municipality of Adja-Ouèrè).

\section{Measurement and data collection}

Spectrum Technologies, model $n^{\circ} 6120$ Inc. compactometer was used to measure the vertical resistance of soils with its two cones (Figure $2 \mathrm{a}$ and $\mathrm{b}$ ). The Eijkelkamp Model $\mathrm{n}^{\circ}$ 0603 pocket penetrometer was used to measure the horizontal resistance of soils (Figure 2c). For the soil particle size distribution, one sample of $1 \mathrm{~kg}$ of soil over $20 \mathrm{~cm}$ depth was collected in one of the localities by municipality (soil type) of each agroecological zone. A total of 12 soil samples were taken to determine the relative proportions of sand, silt and clay particles at the Soil Science Laboratory of the Faculty of Agronomic Sciences of the University of Abomey-Calavi. In addition, by municipality, two undisturbed soil samples were taken using standard cylindrical tubes of $100 \mathrm{~cm}^{3}$ volume at the same sites, ie a total of 24 samples. These samples were packaged in black bags to prevent water loss. On these samples, the wet and dry masses, the volume and the water content of the soils were measured at the Laboratory of Hydraulics and Water Control of the Faculty of Agronomic Sciences of the University of Abomey-Calavi. . The weight of the sample dried at $105^{\circ} \mathrm{C}$, for 72 hours in the oven, relative to the volume of the starting 
sample, gives its bulk density as indicated by the following relationship:

$$
\gamma_{d}=\frac{W s}{V}
$$

$\gamma_{d}$ : bulk density; Ws: weight of solid particles and V: total (apparent) volume of soil.

The moisture content of the soil (Wc) is obtained by the relationship:

$$
W c=\frac{W w-W d}{W d} \times 100
$$

with: Ww:wet weight of soil; Wd: dry weight of soil after drying. Soil resistance to penetration of penetrometer was measured in situ. For this purpose, the vertical resistance was measured at depths $0-10 \mathrm{~cm}$ and $10-20 \mathrm{~cm}$ with two different compactometer cones $(1 / 2$ inch cone and $3 / 4$ inch cone) in three replicates per site. Horizontal resistance was measured using a manual penetrometer at depths $0-10 \mathrm{~cm}$ and $10-20 \mathrm{~cm}$ in three replicates per site.

\section{Statistical analyzes of the data}

The transformation method of Box and Cox (1964) was used to establish the relationship between vertical resistance and horizontal soil resistance, and on the other hand the relationship between soil density or soil moisture content and the vertical resistance. Then the data were adjusted to the models selected to obtain the equations. An analysis of variance was performed to assess the effects of agropedological variation on the physical and mechanical parameters of Benin soils. The separation of means in case of significant difference was made with the Newman-Keuls test to group similar agroecological zones according to each parameter. All statistical analyzes were performed with the R.3.3.0 software. Differences are considered significant at $95 \%$ confidence level $(\mathrm{p}<0.05)$.

\section{RESULTS}

\section{Physical properties of soil of Benin}

Table 2 shows the textural classification of soils over $20 \mathrm{~cm}$ deep. It is noted that the majority of soils assessed are sandy-loamy. The percentage of sand varies from $13.14 \%$ to $80.59 \%$, that of silt ranges from $4.82 \%$ to $32.90 \%$ and for clay from $8.84 \%$ to $53.58 \%$. The high levels of sand in most soils would be due to the depth. The presence of gravels were observed in most samples collected in agroecological zones of northern Benin. Variation of bulk density and soil moisture content is summarized in Table 3. Bulk densities range from 1.21 to $1.73 \mathrm{~g} \mathrm{~cm}^{-3}$. Going down from $0-10 \mathrm{~cm}$ depth to the $10-20 \mathrm{~cm}$ layer, bulk densities increase from 0.02 to 0.48 $\mathrm{g} \mathrm{cm}^{-3}$ in $62.5 \%$ of agroecological zones; they decrease from 0.03 to $0.11 \mathrm{~g} \mathrm{~cm}^{-3}$ in $50 \%$ of cases. The water contents vary between 4.9 and $35.11 \%$. The variation between depths ranging from $0-10 \mathrm{~cm}$ to $10-20 \mathrm{~cm}$ increases from 0.36 to $2.16 \%$ for $50 \%$ of samples against a decrease of 0.35 to $20.68 \%$ in $75 \%$ in most of the agroecological zones.

Vertical and horizontal resistance of soil in different agroecological zone and studied depths

Table 4 presents the average values of resistance according to the depth and the agroecological zone. The vertical strength varies from $5.77 \pm 3.69$ to $13.57 \pm 2.07 \mathrm{~kg} \mathrm{~cm}^{-}$ ${ }^{2}$ for $0-10 \mathrm{~cm}$ depth; and from $5.77 \pm 3.69$ to $14.84 \pm 6.23 \mathrm{~kg} \mathrm{~cm}^{-2}$ for $10-20$ cmdepth. The horizontal resistance ranges from $1.07 \pm 0.19$ to $4.39 \pm 1.10 \mathrm{~kg} \mathrm{~cm}^{-2}$ for $0-10 \mathrm{~cm} \mathrm{depth}$; and from $1.45 \pm 0.42$ to $4.40 \pm 0.85 \mathrm{~kg} \mathrm{~cm} \mathrm{~cm}^{-2}$ for $10-20$ cmdepth. In general, the strongest soil resistances (vertical and horizontal) were recorded in the northern part of Benin where significant proportions of gravels were observed in the samples taken.

\section{Relationship between the parameters studied on the different soil types in Benin}

Figure 3 and 4 illustrates the relationship between the dfferents parameters studied. The evolution of horizontal soil resistance as a function of the vertical resistance of soils to the penetration of penetrometer is showed by figure 3 . The regression equation between vertical resistance (VR) and horizontal resistance (HR) of soils at the penetration of penetrometer is in the form $\mathrm{LnHR}=\mathrm{a}+$ bVR.This model was established thanks to the transformation method of Box and Cox (1964). The equation obtained is:

LnHR=-0.332+ 0.116VR with $\mathrm{R}^{2}=0.75$ In addition, the Pearson correlation coefficient $(\mathrm{r}=0.83, \mathrm{p}=0.000)$ showed a positive correlation between vertical resistance and horizontal soil resistance. Figure 4 shows the evolution in bulk density of soils as a function of vertical resistance. It is noted a small variation of the density of the soil in spite of the high values of soil resistance. The adjusted equation of the regression between the soil resistance and its bulk density gives: $\mathrm{Da}=1,29+0,0267 \mathrm{VR}$ avec $R^{2}=0,32$ The coefficient of determination is weak. 


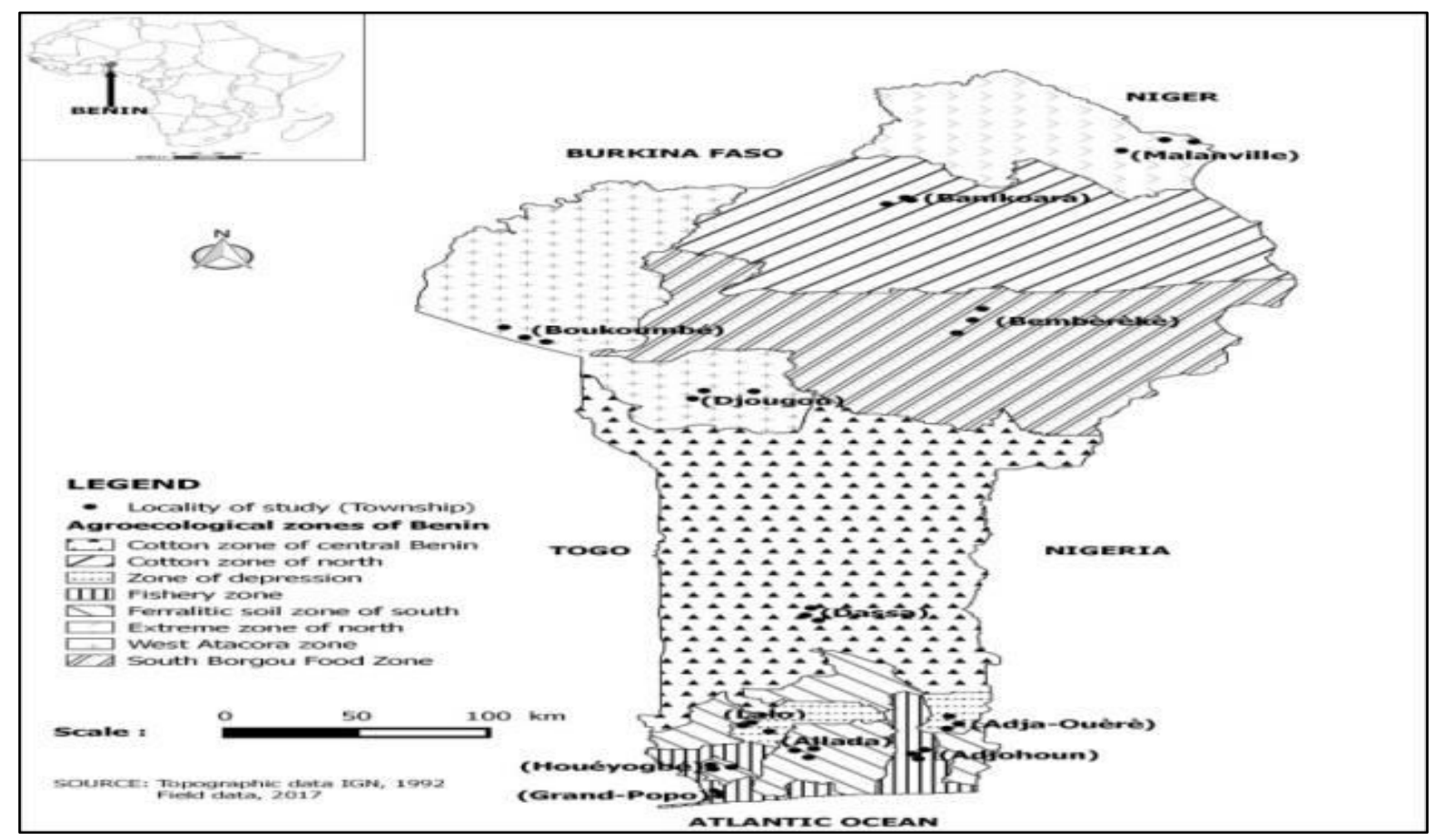

Figure 1 : Presentation of area of study
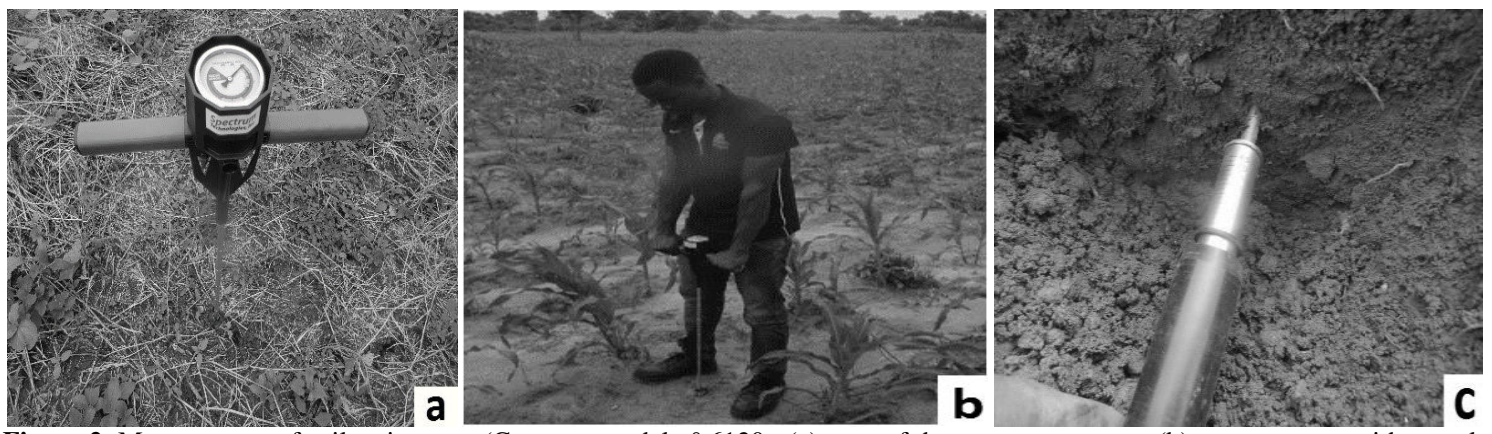

Figure 2: Measurement of soil resistances (Compact model $n^{\circ} 6120$ (a), use of the compactometer (b), measurement with a pocket penetrometer

(c))

The Pearson correlation coefficient $(\mathrm{r}=0.57$; $\mathrm{p}=0.003$ ) showed a positive correlation between the two parameters. Moreover, there is no relation between the water content and the vertical resistance of soils because $R^{2}=0$.

\section{Comparison of parameters between agrocological zones of Benin}

Table 5 presents the results of parmeter comparison between agrocological zones. Overall, with the exception of the water content, a significant difference is noted in the other parameters. The highest bulk densities $\left(\gamma \mathrm{d}>1.5 \mathrm{~g} \mathrm{~cm}^{-3}\right)$ were found in agrocological zones in northern Benin. Vertical resistance has fluctuated widely between agrocological zones. The greatest vertical resistance is found in zones 2, 3, 4, and 5 north of the study area and the smallest are found in zones 6,7 and 8 in the south of the country. As for the horizontal resistance of soils, they have also varied ; the highest are recorded in zones 3,4 and 5 .

\section{DISCUSSION}

Vertical and horizonatal resistances of soil to the penetration of penetrometer

The horizontal resistances increase when the vertical resistances increase. The average vertical resistance is $8.84 \mathrm{~kg} \mathrm{~cm}^{-2}$ against 2.15 $\mathrm{kg} \mathrm{cm}{ }^{-2}$ for the horizontal resistance. These values are high compared to those obtained by Dayou et al.(2017) ranging from 1.8 to $2.1 \mathrm{~kg}$ $\mathrm{cm}^{-2}$ on clay-loam soil regardiless of the cropping system. Richard (2008) pointed out that, for field crops and forests, the highest stresses are approximately $1.84 \mathrm{~kg} \mathrm{~cm}^{-2}$ and can reach $2.55 \mathrm{~kg} \mathrm{~cm}^{-2}$. However, these soil resistances correspond to an average value on the surface of contact and can locally reach the double according to Richard (2008). The cone surfaces of the penetrometer used are $1.613 \mathrm{~cm}^{2}$ and $3.629 \mathrm{~cm}^{2}$. 
However, it is accepted tha $t$ in practice, tips with sections ranging from $5 \mathrm{~cm}^{2}$ to $15 \mathrm{~cm}^{2}$ give values very close to peak resistance (Ali, 2010). For dimensions outside this range, according to Ali (2010). It is recommended that some corrections be considered. The sinking or threshing operations carried out during the execution of static or dynamic penetrometer tests or the scissometer charaeterization tests are hampered by the presence of large elements (pebbles or blocks) in coarse soils (Pedro, 2004). This was also observed during this study where some lateritic soils due to the presence of small solid concrestions (granules) were highly resistant to penetrometer, in the case of agroecological zones 2, 3 and 4. These soils referred to as "granular soil" are lesscompressible. Their settlement was almost instantaneous with the application of the load and does not depend on their water content (Degoutte and Royet, 2009). Billot (1982) emphasizes that pebbly and plastic clay soils should be excluded from penetrometry analyzes. Indeed, the presence of rocks can lead to a frequent blocking of the penetrometer or give abnormally high " index cone', value. As for the clay soils, with certin water contents, they become so sticky that the friction rises very significantly. This makes it difficult to interprct the results correctly. The study of the relationship between verical and horizontal resistances has been less addressed in the past. Most studies consider the soil as a three-dimensional zone whose vertical dimension is often preferred. The horizontal layers are neglected and assumed to extend in the horizontal direction (Breysse et al. 2002). Other authors have focused on the relationship between pre-consolidation pressure and soil resistance to the penetrometer (Ajayiet et al. 2009) and the comparison between manual and automatic penetrometer (Ajayi et al.2010 or between a manual penetrometer and the hydraulic penetrometer (Breune, 1997). But less studies have focused on relationship between horizontal and vertical soil resistances.

\section{Bulk density, texture and vertical resistance of soils}

The obtained results showed that the highest bulk densities appear in agreement with the strongest resistances. However, the highest resistance has been found especially in soils with coarse fragments. It could be said that soil resistance to stress varies with soil texture and bulk density. However, other factors such as the presence of coarse fragments or the organic matter content also influence soil resistance. The results of our study confirm the work of Gbemavo et al. (2014) who found that the main soil physical characteristics (depth, texture) of soils do not vary significantly from one agroecological zone to another. In addition, the various measured parameters were related to the depth considered for the study. That is the $20 \mathrm{~cm}$ depth, which is considered as the ideal ploughing depth, favorable to the best maize yields in Benin (Zokpodo et al., 2017). The measurement of soil resistance to the penetrometer can be affected by the physical effort of the person doing the measurement (Herrick and Jones, 2002), which may influence the results. In addition, Medeiros et al. (2010) found a similarity between the results obtained using a manual penetrometer and those obtained with the electronic penetrometer when detecting the critical depth of compaction of three types of soil: silty, clayey and sandy. In all cases, penetrometer resistance strongly depends on the soil bulk density, texture, structure and soil organic matter content (Cassel, 1982; Bogunovic et al., 2016). It should also be noted that soil compaction can vary significantly in space depending on land use. For that, the ideal would be to measure the resistance of the soil on a precise space in order to highlight the effects of the previous agricultural uses on the soil compaction (Carrara et al., 2003).

In sandy- loamy soils, for example, the resistance of the soil to the penetrometer increases with the constraint of the plant to take root; but only varies for a given constraint in the case of clay soil and is more dependent on soil density (Whalley et al., 2004). However, the author mentions that the prediction of soil resistance from the constraint of the plant is effective only on compressible soils.

\section{Water content and soil resistance}

Nosignificant relationship was observed between soil resistance and moisture content. This result is close to that of Farrell and Greacen (1966) who reported after a linear regression that soil resistance to the penetrometer is not significantly related to their water content. In addition, this absence of relationship between the two parameters is due to the variability of soil types. The work of Hernanz et al. (2000) found a non-linear relationship between soil resistance and water content; with however a variation of this relationship from one type of soil to another. Thus, the results of establishing a link between the water content of a soil and its resistance to the penetrometer are significant 
only if one type of soil is taken into account. According to Adamchuk et al. (2003) looking for a prediction of soil moisture content from penetrometer resistance would be of paramount importance in the fast data collection and could be used for commercial purposes. Panwar and Sirohi (1980) evaluated critical parameters for good development and rooting of wheat and maize in sandy soil. Their work showed that the minimum water content for germination and development of wheat and maize is $10 \%$. A study conducted by Breune (1997) has confirmed that penetration resistance measurements are significantly influenced by phenomena that do not influence bulk density, water content, or yield. Thus, to be able to interpret the results correctly, it is preferable to operate in a wellwetted soil, with the most homogeneous humidity possible (Billot, 1982).

Table 1 presents the pedoclimatic characteristics and major crops cultivated in the study environment based on agroecological zone.

\begin{tabular}{|c|c|c|c|}
\hline Agroecological zone & Climate & Soil & Main crops \\
\hline Zone 1 : Extreme North & $\begin{array}{l}\text { Sudano-sahelian with a rainy } \\
\text { season less than } 900 \mathrm{~mm} / \text { year }\end{array}$ & $\begin{array}{l}\text { Ferruginous on sandstone or } \\
\text { alluvial basement very fertile of } \\
\text { Niger River }\end{array}$ & $\begin{array}{l}\text { Mil, sorghum, cotton, maize, rice, } \\
\text { onion, potato and market gardening }\end{array}$ \\
\hline $\begin{array}{l}\text { Zone } 2 \text { : cotton zone of } \\
\text { north of Benin }\end{array}$ & $\begin{array}{l}\text { Sudan with a rainy season of } \\
1000 \text { to } 1300 \mathrm{~mm} \text { / year }\end{array}$ & $\begin{array}{l}\text { Tropical ferruginous on a } \\
\text { crystalline base with large } \\
\text { proportions of deep and little } \\
\text { concreted soils }\end{array}$ & Sorghum, maize, yams and cotton \\
\hline $\begin{array}{l}\text { Zone } 3 \text { : South Borgou } \\
\text { food zone }\end{array}$ & $\begin{array}{l}\text { Sudan with a single rainy } \\
\text { season of } 900 \text { to } 1300 \mathrm{~mm} / \\
\text { year }\end{array}$ & $\begin{array}{l}\text { Tropical ferruginous with very } \\
\text { variable characteristics }\end{array}$ & Yam, cotton, maize and cashew \\
\hline $\begin{array}{l}\text { Zone } 4 \text { : West Atacora } \\
\text { zone }\end{array}$ & $\begin{array}{l}\text { Sudano-sahelian to Sudano- } \\
\text { guinean variation with an } \\
\text { annual rainfall of } 1000 \text { to } 1300 \\
\text { mm / year }\end{array}$ & $\begin{array}{l}\text { Ferruginous on base often deep, } \\
\text { low water reserve or Ferrallitic } \\
\text { concretion and cuirass on gneiss } \\
\text { and migmatites in places }\end{array}$ & $\begin{array}{l}\text { Cereals in the north of the zone, } \\
\text { completed by the yam in the southern } \\
\text { part }\end{array}$ \\
\hline $\begin{array}{l}\text { Zone } 5 \text { : Cotton zone of } \\
\text { central Benin }\end{array}$ & $\begin{array}{l}\text { Sudano-guinean with two rainy } \\
\text { seasons in the South and a rainy } \\
\text { season in the North. Rainfall } \\
\text { from } 1000 \text { to } 1200 \mathrm{~mm} \text { / year. }\end{array}$ & $\begin{array}{l}\text { Tropical Ferruginous on crystalline } \\
\text { base of very variable } \\
\text { characteristics }\end{array}$ & Cereals, tubers, leguminous and cotton \\
\hline $\begin{array}{l}\text { Zone } 6 \text { : Ferralitic soil zone } \\
\text { of south }\end{array}$ & $\begin{array}{l}\text { Sudano-Guinean with two rainy } \\
\text { seasons with } 600 \text { to } 1200 \mathrm{~mm} \text { / } \\
\text { year in the west and } 1000 \text { to } \\
1400 \mathrm{~mm} \text { / year in Eastern } \\
\text { modal }\end{array}$ & $\begin{array}{l}\text { Ferrallitic, on sandy-clay sediment } \\
\text { and Hydromorphous little } \\
\text { humiferous with pseudo-gley, on } \\
\text { alluvium }\end{array}$ & Maize, cassava, cowpea and peanut \\
\hline Zone 7 : zone of depression & $\begin{array}{l}\text { Sudano-Guinean with two rainy } \\
\text { seasons } 800 \text { to } 1200 \mathrm{~mm} \text { / year }\end{array}$ & $\begin{array}{l}\text { Vertisol with very wet soil, finely } \\
\text { structured surface horizon, on } \\
\text { clayey or modal Ferralitic } \\
\text { sediments, on sandy-clay sediment }\end{array}$ & $\begin{array}{l}\text { Maize, cassava, cowpea and market } \\
\text { gardening }\end{array}$ \\
\hline Zone 8 : fishery zone & $\begin{array}{l}\text { Sudano-guinean with two rainy } \\
\text { seasons, } 1000 \text { to } 1400 \mathrm{~mm} / \\
\text { year }\end{array}$ & $\begin{array}{l}\text { Hydromorphous with little } \\
\text { humification to pseudo-gley, on } \\
\text { alluvium or Vertisol with a very } \\
\text { humid soil surface, finely } \\
\text { structured surface horizon, on } \\
\text { clayey sediment }\end{array}$ & $\begin{array}{l}\text { Maize, cassava, cowpea and market } \\
\text { gardening }\end{array}$ \\
\hline
\end{tabular}

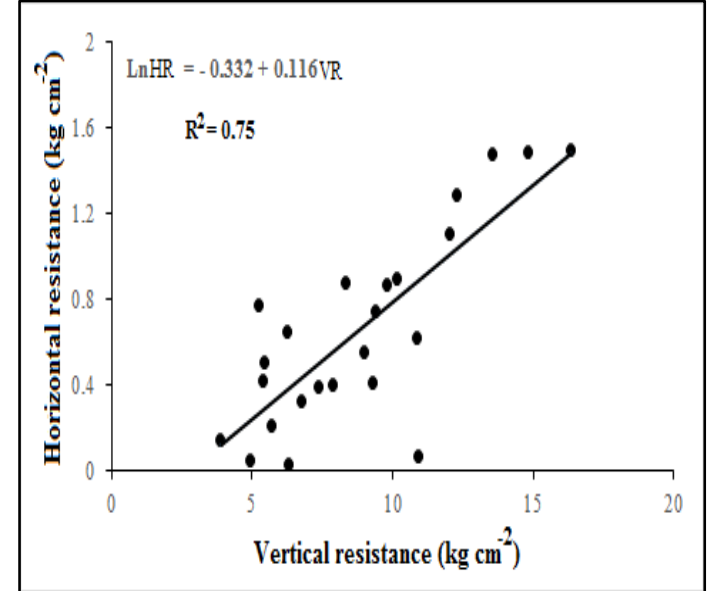

Figure 3 : Horizontal soil resistance as a function of the vertical resistance of soils

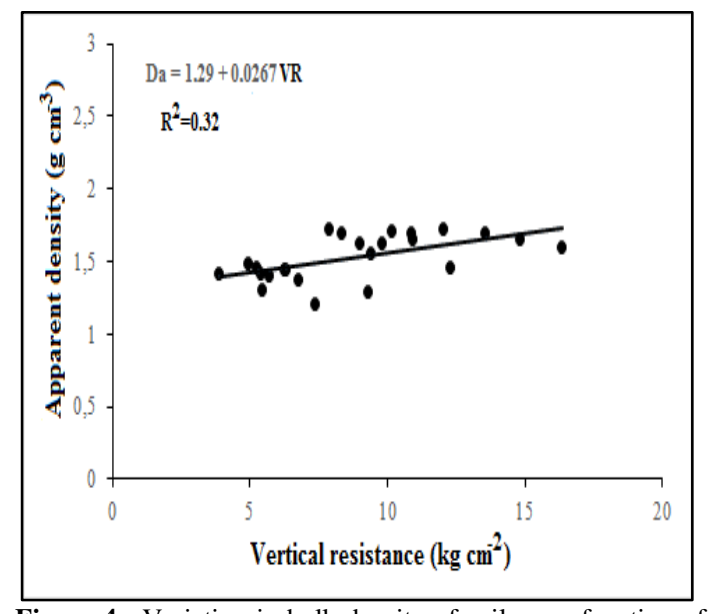

Figure 4 : Variation in bulk density of soils as a function of vertical resistance of soils 
Table 2 : Classification of soil of Benin

\begin{tabular}{|c|c|c|c|c|c|c|}
\hline \multirow[b]{2}{*}{ Agroecological zones } & \multirow[b]{2}{*}{ Municipalities } & \multicolumn{5}{|c|}{ Pourcentage of } \\
\hline & & Sand & Silt & Clay & Textural & Other remarks - \\
\hline & & & & & Classification & \\
\hline Zone 1 & Malanville & 75.56 & 13.16 & 10.52 & Sandy loam & \\
\hline Zone 2 & Banikoara & 68.23 & 20.34 & 11.02 & Sandy loam & Gravel \\
\hline \multirow[t]{2}{*}{ Zone 3} & Bembèrèkè & 69.22 & 18.36 & 11.62 & Sandy loam & Gravel \\
\hline & Djougou & 80.22 & 9.62 & 9.18 & Sandy & Gravel \\
\hline Zone 4 & Boukombé & 64.53 & 18.44 & 16.96 & Sandy clay & Gravel \\
\hline \multirow[t]{2}{*}{ Zone 5} & Dassa & 69.39 & 9.98 & 18.92 & Sandy clay & Clogging \\
\hline & Houéyogbé & 76.28 & 13.06 & 10.32 & Sandy loam & - \\
\hline \multirow[t]{2}{*}{ Zone 6} & Allada & 67.11 & 20.42 & 12.20 & Sandy loam & - \\
\hline & Adja-Ouèrè & 61.28 & 25.30 & 12.46 & Sandy loam & - \\
\hline \multirow[t]{2}{*}{ Zone 7} & Lalo & 69.69 & 21.34 & 8.84 & Sandy loam & - \\
\hline & Grand-Popo & 13.14 & 32.90 & 53.58 & Heavy clay & High clogging \\
\hline Zone 8 & Adjohoun & 80.59 & 4.82 & 14.06 & Sandy clay & - \\
\hline
\end{tabular}

(-) : no particular remarks

Table 3: Bulk density and water content of Benin soils

\begin{tabular}{|c|c|c|c|c|c|c|}
\hline \multirow{2}{*}{$\begin{array}{l}\text { Agroecological } \\
\text { zones } \\
\text { Zone } 1\end{array}$} & \multirow{2}{*}{$\begin{array}{l}\text { Municipalities } \\
\text { Malanville }\end{array}$} & \multirow{3}{*}{$\begin{array}{l}\text { Depth of soil } \\
0-10 \mathrm{~cm} \\
10-20 \mathrm{~cm}\end{array}$} & \multicolumn{2}{|c|}{$\begin{array}{l}\text { Bulk density } \\
\left(\mathrm{g} \mathrm{cm}^{-3}\right)\end{array}$} & \multicolumn{2}{|c|}{ Water content $(\%)$} \\
\hline & & & 1.73 & & 12.6 & \\
\hline & & & 1.63 & $(-0.10)$ & 14.76 & (2.16) \\
\hline \multirow[t]{2}{*}{ Zone 2} & Banikoara & $0-10 \mathrm{~cm}$ & 1.65 & & 15.16 & \\
\hline & & $10-20 \mathrm{~cm}$ & 1.69 & (0.04) & 13.66 & $(-1.5)$ \\
\hline \multirow[t]{2}{*}{ Zone 3} & Bembèrèkè & $0-10 \mathrm{~cm}$ & 1.69 & & 7.58 & \\
\hline & & $10-20 \mathrm{~cm}$ & 1.66 & $(-0.03)$ & 8.96 & (1.38) \\
\hline \multirow[t]{4}{*}{ Zone 4} & Djougou & $0-10 \mathrm{~cm}$ & 1.56 & & 11.85 & \\
\hline & & $10-20 \mathrm{~cm}$ & 1.63 & (0.07) & 8.92 & $(-2.93)$ \\
\hline & Boukombé & $0-10 \mathrm{~cm}$ & 1.46 & & 12.88 & \\
\hline & & $10-20 \mathrm{~cm}$ & 1.6 & $(0.14)$ & 12.53 & $(-0.35)$ \\
\hline \multirow[t]{2}{*}{ Zone 5} & Dassa & $0-10 \mathrm{~cm}$ & 1.71 & & 17.77 & \\
\hline & & $10-20 \mathrm{~cm}$ & 1.73 & $(0.02)$ & 18.13 & $(0.36)$ \\
\hline \multirow[t]{4}{*}{ Zone 6} & Houéyogbé & $0-10 \mathrm{~cm}$ & 1.30 & & 17.32 & \\
\hline & & $10-20 \mathrm{~cm}$ & 1.44 & $(0.14)$ & 12.09 & $(-5.23)$ \\
\hline & Allada & $0-10 \mathrm{~cm}$ & 1.42 & & 12.29 & \\
\hline & & $10-20 \mathrm{~cm}$ & 1.46 & $(0.04)$ & 11.51 & $(-0.78)$ \\
\hline \multirow[t]{4}{*}{ Zone 7} & Adja-Ouèrè & $0-10 \mathrm{~cm}$ & 1.21 & & 35.11 & \\
\hline & & $10-20 \mathrm{~cm}$ & 1.69 & $(0.48)$ & 14.43 & $(-20.68)$ \\
\hline & Lalo & $0-10 \mathrm{~cm}$ & 1.48 & & 15.45 & \\
\hline & & $10-20 \mathrm{~cm}$ & 1.42 & $(-0.06)$ & 16.28 & $(0.83)$ \\
\hline \multirow[t]{4}{*}{ Zone 8} & Grand-Popo & $0-10 \mathrm{~cm}$ & 1.4 & & 27.15 & \\
\hline & & $10-20 \mathrm{~cm}$ & 1.29 & $(-0.11)$ & 22.55 & $(-4.6)$ \\
\hline & Adjohoun & $0-10 \mathrm{~cm}$ & 1.45 & & 5.47 & \\
\hline & & $10-20 \mathrm{~cm}$ & 1,37 & $(-0.08)$ & 4.90 & $(-0.57)$ \\
\hline
\end{tabular}

Numbers in bracket are the difference between the lower layer $(10-20 \mathrm{~cm})$ and the upper one $(0-10 \mathrm{~cm})$.

Table 4: Average and standard error of soil resistance by depth and agroecological zone of Benin

\begin{tabular}{llcc}
\hline Agroecological zones & Depth of soil & $\begin{array}{c}\text { Vertical resistances of soil }(\mathrm{kg} \\
\left.\mathrm{cm}^{-2}\right)\end{array}$ & $\begin{array}{c}\text { Horizontal resistances of soil }(\mathrm{kg} \\
\left.\mathrm{cm}^{-2}\right)\end{array}$ \\
\hline Zone 1 & $0-10 \mathrm{~cm}$ & $7.90 \pm 1.26$ & $1.49 \pm 0.51$ \\
& $10-20 \mathrm{~cm}$ & $9.01 \pm 2.33$ & $1.73 \pm 0.60$ \\
Zone 2 & $0-10 \mathrm{~cm}$ & $10.90 \pm 3.88$ & $1.07 \pm 0.19$ \\
& $10-20 \mathrm{~cm}$ & $10.86 \pm 4.71$ & $1.86 \pm 0.45$ \\
Zone 3 & $0-10 \mathrm{~cm}$ & $13.57 \pm 2.07$ & $4.39 \pm 1.10$ \\
& $10-20 \mathrm{C006D}$ & $14.84 \pm 6.23$ & $4.40 \pm 0.85$ \\
Zone 4 & $0-10 \mathrm{~cm}$ & $8.97 \pm 3.59$ & $2.86 \pm 1.02$ \\
& $10-20 \mathrm{~cm}$ & $10.53 \pm 4.46$ & $3.41 \pm 1.16$ \\
Zone 5 & $0-10 \mathrm{~cm}$ & $10.18 \pm 2.74$ & $2.45 \pm 0.41$ \\
& $10-20 \mathrm{~cm}$ & $12.01 \pm 3.84$ & $3.01 \pm 0.41$ \\
Zone 6 & $0-10 \mathrm{~cm}$ & $5.42 \pm 4.07$ & $1.59 \pm 0.75$ \\
& $10-20 \mathrm{~cm}$ & $5.77 \pm 3.69$ & $2.05 \pm 0.78$ \\
Zone 7 & $0-10 \mathrm{~cm}$ & $6.15 \pm 1.92$ & $1.27 \pm 0.36$ \\
& $10-20 \mathrm{~cm}$ & $6.11 \pm 3.07$ & $1.78 \pm 0.75$ \\
Zone 8 & $0-10 \mathrm{~cm}$ & $6.00 \pm 1.12$ & $1.13 \pm 0.38$ \\
& $10-20 \mathrm{~cm}$ & $8.04 \pm 2.99$ & $1.45 \pm 0.42$ \\
\hline
\end{tabular}


Table 5: Mean and standard error of the physical parameters of agroecological zones

\begin{tabular}{lllll}
\hline Agroecological zones & Bulk density $\left(\mathrm{gcm}^{-3}\right)$ & $\begin{array}{l}\text { Water } \\
(\%)\end{array}$ & $\begin{array}{c}\text { content } \\
(\mathrm{kg} \mathrm{cm})\end{array}$ & $\begin{array}{l}\text { Vertical resistance } \\
\left(\mathrm{kg} \mathrm{cm}^{-2}\right)\end{array}$ \\
\hline Zone 1 & $1.68 \pm 0.07^{\mathrm{ab}}$ & $13.68 \pm 1.53^{\mathrm{NS}}$ & $8.45 \pm 0.79^{\mathrm{cd}}$ & $1.61 \pm 0.26^{\mathrm{c}}$ \\
Zone 2 & $1.67 \pm 0.03^{\mathrm{ab}}$ & $14.41 \pm 1.06^{\mathrm{NS}}$ & $10.88 \pm 0.03^{\mathrm{bc}}$ & $1.47 \pm 0.47^{\mathrm{c}}$ \\
Zone 3 & $1.68 \pm 0.02^{\mathrm{ab}}$ & $8.27 \pm 0.98^{\mathrm{NS}}$ & $14.20 \pm 0.89^{\mathrm{a}}$ & $4.39 \pm 0.179^{\mathrm{a}}$ \\
Zone 4 & $1.60 \pm 0.02^{\mathrm{abc}}$ & $13.03 \pm 3.25^{\mathrm{NS}}$ & $12.17 \pm 1.31^{\mathrm{ab}}$ & $3.22 \pm 0.97^{\mathrm{b}}$ \\
Zone 5 & $1.72 \pm 0.01^{\mathrm{a}}$ & $17.95 \pm 0.25^{\mathrm{NS}}$ & $11.10 \pm 1.30^{\mathrm{bc}}$ & $2.73 \pm 0.69^{\mathrm{b}}$ \\
Zone 6 & $1.41 \pm 0.06^{\mathrm{cd}}$ & $13.30 \pm 2.12^{\mathrm{NS}}$ & $5.60 \pm 0.24^{\mathrm{d}}$ & $1.81 \pm 1.00^{\mathrm{c}}$ \\
Zone 7 & $1.45 \pm 0.15^{\mathrm{bcd}}$ & $20.32 \pm 7.02^{\mathrm{NS}}$ & $6.13 \pm 0.03^{\mathrm{d}}$ & $1.52 \pm 0.55^{\mathrm{c}}$ \\
Zone 8 & $1.38 \pm 0.07^{\mathrm{d}}$ & $15.02 \pm 1.83^{\mathrm{NS}}$ & $7.02 \pm 1.44^{\mathrm{d}}$ & $1.29 \pm 0.45^{\mathrm{c}}$ \\
Probability & $\mathrm{p}=0.00^{* *}$ & $\mathrm{p}=0.08^{\mathrm{NS}}$ & $\mathrm{p}=0.00^{* * *}$ & $\mathrm{p}=0.00^{* * *}$ \\
\hline Each value is an average \pm standard error. Numbers with different letters in the same column are significantly different at \\
5\% threshold according to the Newman-Keuls test. NS: not significant; **: significant difference at $1 \%$ level; ***: \\
significant difference at 0.1\% level.
\end{tabular}

\section{CONCLUSION}

The results of this study showed a small variation in soil bulk density. There is a relationship between vertical resistance and horizontal soil resistance. Weakrelationship was observed between bulk densities and soil resistance on the one hand; and no relationship between resistances and the water contents on the other hand. It appears necessary to use the penetrometer for local measurements of each situation in order to be more satisfied with the expected resistances. The relatively low cost of the penetrometers used, the easy use with their low maintenance and easy transport is an advantage to their use compared to other gigantic penetrometer. It is also important to either measure at different times of the year to obtain a better characterization, or to use a specific period to ensure comparability.

\section{ACKNOWLEDGEMENT}

This research was supported by the International Foundation for Science, Sweden, through a research grant to DAYOU Ephrème Dossavi.

\section{REFERENCES}

Abdellaoui Z., Teskrat H., Belhadj A., Zaghouane O. (2011). Etude comparative de l'effet du travail conventionnel, semis direct et travail minimum sur le comportement d'une culture de blé dur dans la zone subhumide. In: Bouzerzour H. (ed.), Irekti H. (ed.), Vadon B. (ed.). 4. Rencontres Méditerranéennes du Semis Direct.

Zaragoza : CIHEAM / ATU-PAM / INRAA / ITGC / FERT, $2011: p p 71-87$.

Adamchuk V. I., Skotnikov A.V., Speichinger J. D., Kocher M. F. (2003). Instrumentation System for Variable Depth Tillage. In Proceedings of

ASAE Annual International Meeting, Las Vegas, NV, USA, July 27-30, 2003; Paper No. 03-1078.

Adnan N. S., Mohsin T., Babar S., Guozheng Y., Shah F., Saif A.,Muhammad A. B., Shahbaz T.,Abdul H., Biangkham S. (2017). Soil compaction effects on soil health and crop productivity: an overview. Environ Sci Pollut Res, 13p.

Ajayi A. E., Dias Junior M. S., Curi N., Okunola A., Teixeira Souza T. T. and Silva Pires B. (2010). Assessment of vulnerability of Oxisols to compaction in the Cerrado Region of Brazil. Pedosphere 20: 1-10.
Ajayi, A. E., Dias Junior M. S., Curi N., Junior C. F. A., Aladenola O. O., Teixeira Souza T. T. T., Junior A. V. I. (2009). Comparison of estimation methods of soil strength in five soils. R. Bras. Ci. Solo, 33: 487-495, 2009.

Ali H. (2010). Caractérisation améliorée des sols par l'essai de chargement de pointe au piézocône. Application au calcul des fondations profondes. Thèse de doctorat, Université Blaise Pascal - Clermont-Ferrand II, 2010. 324p.

Ball B. C., Batey T., Munkholm L. J., Guimares R. M. L., Boizard H., McKenzie D. C., Peigne J., Tormena C. A. and Hargreaves P.(2015). The numeric visual evaluation of subsoil structure (SubVESS) under agricultural production. Soil \& Tillage Research, 148: pp. 85-96. ISSN 0167-1987.

Billot J. F. (1982). Les applications agronomiques de la pénétrométrie à l'étude de la structure des sols travaillés. Sci. Sol. 3: 187-202.

Birkas M., Szemok A., Antos G., Nemenyi M. (2008). Environmentally sound adaptable tillage. Akadémiai Kiado.p7.

Bogunovic I., Dekemati I., Magdic I., Vrbanic M., Matosic S., Mesic M. (2016). Spatial modelling for describing spatial variability of soil physical properties in eastern Croatia. POLJOPRIVREDA 22:2016 (1), 46-52.

Box G. E. P. and Cox D. R. (1964). An analysis of transformations. Journal of the Royal Statistical Society. Series B (Methodological), 26: 211-252.

Breune I. (1997). Le Pénétromètre: Un outil de détermination de la qualité structurale des Sols? Mémoire présenté la Faculté des études supérieures de l'Université Laval pour l'obtention du grade de maître és sciences (M.Sc.). Septembre 1997, 88p.

Breysse D., Niandou H., Rodier X., Galinié H. et Laurent A. (2002). Le pénétromètre et l'hétérogénéité des sols archéologiques urbains. Revue Française de géotechnique, $N^{\circ} 100$, 3e trimestre 2002.

Carrara M., Comparetti A., Febo P., Morello G., Orlando S. (2003). Mapping soil compaction measuring Cône penetrometer resistance. Conference Paper,Precision Agriculture, Dipartimento I.T.A.F., Università di Palermo, Viale delle Scienze, 13, Palermo, Italy, June 2003, $9 p$.

Cassel D.K. (1982). Tillage effects on soil bulk density and mechanical impedance. In: P.W. Unger, D.M. Van Doren $J r$. (ed.): Predicting tillage effects on soil physical properties and processes, ASA Special Publication Number, 44: 45-67. 
Daniel P. S., Pablo J. D., Christian S. and Klaus J. P. (2015). Light availability and soil compaction influence the growth of underplanted Nothofagus following partial shelterwood harvest and soil scarification. Can. J. For. Res. 45: 998-1005.

Dayou E. D., Rakoto B. and Zokpodo B. L. (2017). Physical behavior of andosols under different levels of mechanization: case of malagasy highlands. In: International Research Journal of India, Vol.2, Issue. 7,11p.

Degoutte G et Royet P. (2009). Aide-mémoire de mécanique des sols.Les publications de l'ENGREF, Réédition 2009, 96p.

Dexter A. R., Czyz E. A., Gate O. P. (2007). A method for prediction of soil penetration resistance. Soil \& Tillage Research 93: 412-419.

Farrell D.A., Greacen E.L.(1966). Resistance to penetration of fine probes in compressible soil. Aust. J. Soil Res. 4, $1-17$.

Gbemavo D. S. J. C., Gnanglé P. C., Azontondé A. et Glèlè Kakaï, R. L. (2014). Modélisation du stock de biomasse et dynamique de séquestration minérale et du carbone de Jatropha curcas $l$. sous différents types de sol au bénin. Annales des Sciences Agronomiques 18 : (1) : 1-21.

Hernanz J.L., Peixoto H., Cerisola C., Sanchez-Geron V.(2000). An empirical model to predict soil bulk density profiles in field conditions using penetration resistance, moisture content and soil depth. $J$. Terramech. $37: 67-184$.

Lenoble A. andMartinaud M. (2003). Apports du pénétrométre à la connaissance d'un site préhistorique. Le cas de l'abri de Diepkloof, province du Cap, Afrique du Sud. In: Revue d'Archéométrie, $n^{\circ} 27$ : 2003. pp. $27-$ 36.

Lepetit L., Bacconnet C., Boissier D., Gourvès R. (2000). Geostatistical studv of the Chinese loess. ICASP7: Sydney, ed. Balkema, 2000 p491-498.

Ministère de l'Agriculture, de l'Elevage et de la Pêche, (2010). Rapport d'étude du prix plancher du maïs au titre de la campagne 2010-2011 Ministère de l'agriculture, de l'élevage et de la pêche, décembre 2010, pp7-9.

Medeiros J. C., Figueiredo G. C., Mafra A. L. (2010). Portable penetrometer for agricultural soil: sensitivity test to identify critical compaction depth. R. Bras. Ci. Solo, 34- : 1823-1829, 2010.

Mekhlouf A., Makhlouf M., Achiri A., Ait Ouali A.and Kourougli S. (2011). Etude comparative de l'effet des systèmes de travail du sol et des précédents culturaux sur le sol et le comportement du blé tendre (Triticum aestivum L.) en conditions semi-arides. Agriculture $N^{\circ} \mathbf{2}$ : 2011, 52-65.

Panwar J. S. and Sirohi N. P. S. (1980). Critical parameters of plant emergence and root growth. Journal of Agricultural Engineering, 27 :(3-4), 9-17.

Pedro L. S. (2004). De l'étude du comportement mécanique de sols hétérogènes modèles à son application au cas des sols naturels.Sciences de l'ingénieur [physics]. Ecole des Ponts ParisTech, 2004. 295p.

Richard G. (2008). Dégradation physique des sols agricoles et forestiers liée au tassement. Rapport scientifique détaillé, décembre 2008, 50p.

Steve L. andCaroline P. (2017). Evaluation de la période d'implantation des engrais verts sur les pratiques culturales et les cultures. Rapport final du projet 13-SCS04. Centre de recherche agroalimentaire de Mirabel. 37p.

UNDP/ECVR, (1995). Carte des zones cagroécologiques du Bénin. 1p.

Whalley W. R., Tob J., Kay B. D., Whitmore A. P. (2007). Prediction of the penetrometer resistance of soils with models with few parameters. Geoderma 137: 370-377.

Whalley W.R., Leeds-Harrisonb P.B., Clarka L.J., Gowing D.J.G. (2004). Use of effective stress to predict the penetrometer resistance of unsaturated agricultural soils. Soil \& Tillage Research 84: 18-27.

Willaime M. M. P. and Volkoff B. (1967). Carte pédologique du Dahomey à l'échelle 1:1000 000. Office de la Recherche Scientifique et Technique Outre-Mer, Centre de Cotonou.

Zokpodo K. L. B., Akossou A. Y. J., Dayou E. D. and Dognon F. B. (2017). Contribution to the determination of the optimal ploughing depth on tropical ferruginous soil in northern Benin: impact on soil structure and yield of a corn culture. Int. J. Adv. Res. 5:(6), 32-39. 